\title{
Evaluating the presence of Mycoplasma hyorhinis, Fusobacterium nucleatum, and Helicobacter pylori in biopsies of patients with gastric cancer
}

\author{
Camila do Nascimento Araujo ${ }^{1}$, Aline Teixeira Amorim ${ }^{1}$, Maysa Santos Barbosa', \\ Julieta Canjimba Porto Lucas Alexandre 2 , Guilherme Barreto Campos ${ }^{1,3}$, Cláudia Leal Macedo 4 , \\ Lucas Miranda Marques ${ }^{1,3^{*}}$ [D and Jorge Timenetsky ${ }^{1}$
}

\begin{abstract}
Background: Gastric cancer is the third leading cause of cancer-related deaths worldwide and has been associated with infections that may promote tumour progression. Accordingly, we analysed the presence of Mollicutes, Mycoplasma hyorhinis, Fusobacterium nucleatum and Helicobacter pylori in gastric cancer tissues and evaluated their correlation with clinicopathological factors.

Methods: Using a commercial kit, DNA were extracted from 120 gastric samples embedded in paraffin: 80 from patients with gastric cancer and 40 from cancer free patients, dating from 2006 to 2016 . Mollicutes and H. pylori were detected by PCR; F. nucleatum and M. hyorhinis were detected by GPCR, together with immunohistochemistry for the latter bacteria.

Results: Mollicutes were detected in the case and control groups (12\% and 2.5\%) and correlated with the papillary histologic pattern $(P=0.003)$, likely due to cell transformation promoted by Mollicutes. M. hyorhinis was detected in the case and control group but was not considered a cancer risk factor. H. pylori was detected at higher loads in the case compared to the control group ( $8 \%$ and $22 \%, P=0.008)$ and correlated with metastasis $(P=0.024)$, lymphatic invasion $(P=0.033)$, tumour of diffused type $(P=0.028)$, and histopathological grading $G 1 / G 2(P=0.008)$. F. nucleatum was the most abundant bacteria in the case group, but was also detected in the control group ( $26 \%$ and 2.5\%). It increased the cancer risk factor $(P=0.045, \mathrm{OR}=10.562, \mathrm{Cl} 95 \%=1.057-105.521)$, and correlated with old age $(P=0.030)$ and tumour size $(P=0.053)$. Bacterial abundance was significantly different between groups $(P=0.001)$.
\end{abstract}

Conclusion: Our findings could improve the control and promote our understanding of opportunistic bacteria and their relevance to malignant phenotypes.

Keywords: Mollicutes, Mycoplasma hyorhinis, Fusobacterium nucleatum, Helicobacter pylori, Gastric cancer

*Correspondence: Imirandamarques@gmail.com

${ }^{1}$ Department of Microbiology, Institute of Biomedical Sciences, ICB/USP, University of São Paulo, São Paulo, Brazil

Full list of author information is available at the end of the article

\section{Background}

The mortality rates due to neoplasia exceed those caused by coronary heart disease or stroke, and the highest rates are reported in low- to middle-income households [1]. Globally, gastric cancer is the fifth most diagnosed and the third leading cause of cancer-related deaths original author(s) and the source, provide a link to the Creative Commons licence, and indicate if changes were made. The images or other third party material in this article are included in the article's Creative Commons licence, unless indicated otherwise in a credit line to the material. If material is not included in the article's Creative Commons licence and your intended use is not permitted by statutory regulation or exceeds the permitted use, you will need to obtain permission directly from the copyright holder. To view a copy of this licence, visit http://creativecommons.org/licenses/by/4.0/. The Creative Commons Public Domain Dedication waiver (http://creativeco mmons.org/publicdomain/zero/1.0/) applies to the data made available in this article, unless otherwise stated in a credit line to the data. 
that mainly affects men over 50 years of age. Its prevalence and prognosis vary considerably between racial and socioeconomic groups. In Brazil, mortality rates due to gastric cancer rank fourth among men and sixth among women [1,2]. Gastric cancer affects different sites in the stomach with macroscopic variations and distinct histological patterns. According to Lauren's classification, stomach cancer can be divided into intestinal type and diffuse type [3]. The development of stomach tumours has primarily been associated with an individual's genetics, environmental factors, and infection with pathogens that induce persistent inflammation. For example, Helicobacter pylori is a pathogen that induces peptic ulcers, neutralises gastric acid, and, with their cag pathogenicity island, maintains a tumour-permissive microenvironment in the gastric mucosa [4].

Opportunistic microorganisms, such as Mollicutes and Fusobacterium nucleatum, are not considered to be type I carcinogens. However, given their prevalence in tumour tissues, their potential roles as oncobacteria deserve investigation. F. nucleatum, a Gram-negative, anaerobic, biofilm-forming, non-spore-forming and non-mobile bacillus, occurs at equilibrium in the oral-gastrointestinal tracts and participates in the health and homeostasis of the oral site [5]. F. nucleatum has also been associated with extraoral diseases such as appendicitis and intestinal inflammation [5]; has been reported in oral, head and neck, cervical and gastric carcinoma tissues; and is commonly associated with colorectal cancer, where it induces a worse prognosis by promoting resistance to chemotherapy [6, 7]. The association of $F$. nucleatum with malignant lesions can be explained by microsatellite instability, alteration of the Cpg island methylator phenotype (CIMP), and mutations in the BRAF, KRAS, and TP53 genes [8]. F. nucleatum can migrate out of the oral site via an oral-gastrointestinal route or haematogenously in a Fap2 adhesin-dependent manner. Fap2 is an adhesin unique to oral Fusobacteria that binds to GalGalNac (a sugar residue overexpressed in tumour tissue) or to the $\mathrm{T}$ cell immunoglobulin and ITIM domain (TIGIT) (a receptor of natural killer cells and lymphocytes), inhibiting the cytotoxic function of these cells and promoting a conducive environment for bacteria and tumour cells [9].

The human microbiome harbours not only F. nucleatum, but also bacteria of the Mollicutes class that may cause or be associated with host immunosuppression $[5,10]$, and have been detected in tissues of patients with chronic gastritis, local inflammation, and neutrophil accumulation [11]. Mollicutes belong to a heterogeneous group of microorganisms that are present in humans, animals, insects, and plants [10]. Most pathogenic species in humans and animals belong to the order Mycoplasmatales, with 160 Mycoplasma species and 8
Ureaplasma species [12]. Mycoplasma species, like the porcine $M$. hyorhinis, are common cell culture contaminants. Mycoplasma hyorhinis can, reportedly, invade mammalian immune cells and has been detected in gastric carcinoma tissues [13, 14].

Mycoplasma hyorhinis has been implicated in several swine diseases [15], with severe pathogenicity, mortality rates, and subsequent economic losses. Attempts to minimise these impacts with antibiotics promote the development of drug resistant $M$. hyorhinis strains, which infect the human stomach via the consumption of porcine products $[11,15]$. A previous report identified $M$. hyorhinis in $56 \%$ of a gastric cancer [16]. Its association with gastric cancer is more common than with other gastric diseases [17] where it is able to induce different profiles that cause chronic superficial gastritis, gastric ulcers, and intestinal metaplasia [16]. Lipoprotein p37, a component of $M$. hyorhinis that possesses a transport system similar to the periplasmic transport systems of Gram-negative bacteria, is believed to promote cell motility and invasion, consequently exacerbating carcinogenesis and metastasis $[18,19]$. These features have been identified both in vitro and in vivo and were associated with the phosphorylation of epidermal growth factor receptor (EGFR) and extracellular signal-regulated kinase 1/2 (ERK1/2) [13]. The EGF binding/receptor system appears to be involved in regulating gastric mucosal proliferation and the progression of gastric carcinomas [20]. M. hyorhinis infection, or the presence of $\mathrm{p} 37$ alone, might induce the phosphorylation of PI3k and AKT, which are EGFR-dependent. Activation of the EGFR-PIK3-AKT pathway is related to the regulation of metabolism, growth, survival, and cell motility; the dysregulation of this pathway has been linked to tumorigenesis and angiogenesis [21].

Infection with $M$. hyorhinis and the p37 protein can potentially promote gastric cancer development, though the underlying mechanism remains unclear and needs further elucidation [13, 21]. Based on the strong association between gastric cancer and infectious agents, we evaluated the relationship between specific clinical variables and infection with Mollicutes as well as F. nucleatum and $H$. pylori. Our study group consisted of individuals with or without gastric cancer from Vitória da Conquista, Bahia (BA), Brazil. Not all samples positive for Mollicutes were positive for $M$. hyorhinis, indicating that other mycoplasma species may be present in the gastric tissue.

\section{Methods}

\section{Study population}

We performed a retrospective study assessing formalinfixed paraffin-embedded (FFPE) gastric fragment samples collected from 2006 to 2016. These samples were obtained from a laboratory of pathological anatomy and 
cytopathology service in Vitória da Conquista, BA, Brazil. In total, 120 samples were examined: 80 from patients with gastric cancer (case group) and 40 from patients undergoing stomach reduction surgery, with intact tissue confirmed by histopathology (control group).

\section{Sample collection}

Gastric fragments of specific tumour areas were aseptically obtained from paraffin blocks; the first section from the paraffin block was consistently discarded [22]. Lesions were evaluated according to the surgical classification of the stomach: (a) cardia, (b) body and fundus, and (c) antrum. The molecular diagnosis of FFPE blocks was performed using five $10-\mu \mathrm{m}$-thick slices stored in $1.5 \mathrm{~mL}$ microtubes. Immunohistochemical (IHC) and histology (haematoxylin-eosin [H\&E] staining) analyses were performed using $4-\mu \mathrm{m}$-thick sections [23].

\section{DNA extraction from formalin-fixed paraffin-embedded (FFPE) gastric fragment samples}

Due to the difficulties in recovering nucleic acids from FFPE samples and the diversity of protocols available in the literature, we selected an optimal method based on assay duration and the viability of extracted DNA. Four methods were in-house and were assessed with and without prior xylol dewaxing, and two other methods were performed using commercial kits and were tested with and without prior xylol and mineral oil dewaxing. After dewaxing the samples, the extraction methods were tested with different digestion buffers, as described:

- Dewaxing with Xylol [24]: This was performed for in-house methods before DNA extraction. In brief, DNA samples were immersed in xylol $(\mathrm{pH} \mathrm{6-7.6)}$ at $65{ }^{\circ} \mathrm{C}$ for $10 \mathrm{~min}$ and then bathed in $99^{\circ}, 96^{\circ}$, and $70^{\circ}$ Gay-Lussac (GL) and volatilised for $30 \mathrm{~min}$.

- Dewaxing with Mineral Oil [25]: This was performed before DNA extraction using commercial kits. Briefly, DNA samples were immersed in mineral oil, incubated for $1 \mathrm{~min}$ at $80^{\circ} \mathrm{C}$, and vortexed.

- Extraction Method 1 (EM1): digestion buffer (pH 7.5), with $1 \mathrm{M}$ Tris-HCl, 1\% SDS (sodium dodecyl sulphate), and PK (proteinase K) (10 mg/mL) [24].

- Extraction Method 2 (EM2): digestion buffer (pH 8.0), with $1 \mathrm{M} \mathrm{NaCl}, 1 \mathrm{M}$ Tris-HCL, 0.5 M EDTA, $10 \%$ SDS, and PK $(0.5 \mathrm{mg} / \mathrm{mL})$ [26].

- Extraction Method 3 (EM3): digestion buffer (pH 8.5), with $50 \mathrm{mM}$ Tris-HCL, $1 \mathrm{mM}$ EDTA, and 0.5\% Tween 20 and PK $(200 \mu \mathrm{g} / \mathrm{mL})$ [16].

- Extraction Method 4 (EM4): digestion buffer (pH 9.0), with $50 \mathrm{mM}$ Tris- $\mathrm{HCl}$ and $\mathrm{PK}(20 \mathrm{mg} / \mathrm{mL})$ [27].
Subsequently, samples were incubated at $95{ }^{\circ} \mathrm{C}$ for $10 \mathrm{~min}$, purified using a solution of phenol/chloroform/ isoamyl alcohol (25:24:1; $\mathrm{pH} 8.0)$, treated with ammonium acetate $(7.5 \mathrm{M})$, precipitated with ice-cold ethanol followed by alcohol baths, and volatilised for $30 \mathrm{~min}$ [28]. Samples were homogenised with $40 \mu \mathrm{L}$ of Tris-EDTA buffer $(10 \mathrm{mM}$ Tris-HCl, $1 \mathrm{mM}$ EDTA, $\mathrm{pH}$ 8.0) and stored at $-20^{\circ} \mathrm{C}$.

- Extraction Method 5 (EM5): after dewaxing, DNA extraction was performed using a ReliaPrep ${ }^{\mathrm{TM}}$ FFPE gDNA Miniprep System (Promega ${ }^{\circledR}$, Madison, WI, USA).

- Extraction Method 6 (EM6): after dewaxing, DNA extraction was performed using a Macherey-Nagel ${ }^{\circledR}$ Tissue Kit (Fisher Scientific ${ }^{\circledR}$, Fair Lawn, NJ, USA).

For each extraction method, the amount and purity of DNA were assessed spectrophotometrically (Nanospectrometer-DS-11, DeNovix ${ }^{\circledR}$, Wilmington, DE, USA).

\section{Molecular detection \\ $\beta$-globin PCR}

The primers $\mathrm{PC} 03 / \mathrm{PC} 04$ for the housekeeping gene $(\beta$-globin) [29] were standardised to verify the quality of the extracted genetic material. Primer sequences and the expected product size are listed in Table 1. Genomic DNA samples were amplified by PCR, and the product size was verified by performing agarose gel $(2 \%)$ electrophoresis. DNA derived from frozen tissue and $\mathrm{Si}-\mathrm{Ha}$ cell culture were used as positive controls, with ultrapure water employed as a negative control. All PCR reactions on FFPE extracted material were performed in duplicate.

To prepare PCR reactions, we used $50 \mathrm{ng} / \mu \mathrm{L}$ of purified DNA from each sample, $1 \times$ buffer (Buffer- $10 \times$ Tris$\mathrm{HCl}$ [pH 8.4], $500 \mathrm{mM} \mathrm{KCl}), 1.6 \mathrm{mM}$ of deoxyribonucleotide triphosphate (dNTP), $1.5 \mathrm{mM}$ of $\mathrm{MgCl}_{2}, 20,000 \mathrm{nM}$ of each primer (Table 1), $0.5 \mathrm{U}$ of Taq DNA polymerase (Invitrogen ${ }^{\circledR}$, São Paulo, SP, Brazil), to achieve a final volume of $25 \mu \mathrm{L}$. The assays were performed in a Veriti Thermal Cycler (Applied Biosystems, São Paulo, SP, Brazil). The reaction parameters were as follows: denaturation of $95^{\circ} \mathrm{C}$ for $5 \mathrm{~min}, 40$ cycles at $95^{\circ} \mathrm{C}$ for $1 \mathrm{~min}$, with different annealing temperatures tested $\left(54-56{ }^{\circ} \mathrm{C}\right)$ for $1 \mathrm{~min}, 72{ }^{\circ} \mathrm{C}$ for $1 \mathrm{~min}$, a final cycle of $72{ }^{\circ} \mathrm{C}$ for $10 \mathrm{~min}$, and a hold step at $4{ }^{\circ} \mathrm{C}$.

\section{Mollicutes, M. hyorhinis, F. nucleatum, and H. pylori detection} Different strains of mycoplasma were cultured, and their DNA was extracted using a PureLink ${ }^{\mathrm{TM}}$ Genomic DNA Mini Kit (Thermo Fisher Scientific, Waltham, MA, USA). M. hyorhinis (ATCC 17981) was cultured in FRISS medium (pH 7.2) [30]; M. bovis (ATCC 19210 - AN5) 
Table 1 Primers used in the PCR assay for detecting $\beta$-globin, Mollicutes, Helicobacter pylori, Fusobacterium nucleatum, and Mycoplasma hyorhinis

\begin{tabular}{|c|c|c|c|c|}
\hline Primer & Sequence $\left(5^{\prime}-3^{\prime}\right)$ & Location & Amplicons & Ref \\
\hline PC03 & ACACAACTGTGTTCACTAGC & nt 1575-1594 & $110 \mathrm{bp}$ & [29] \\
\hline PC04 & CAACTTCATCCACGTTTCAC & nt 1684-1669 & & \\
\hline GPO3 & GGGAGCAAACACGATAGATACCCT & nt $221-245$ & $270 \mathrm{bp}$ & [32] \\
\hline MGSO & TGCACCATCTGTCACTCTGTTAACCTC & nt 491-465 & & \\
\hline JW21 & GCGACCTGCTGGAACATTAC & nt $691-710$ & $138 \mathrm{bp}$ & [33] \\
\hline JW22 & CGTTAGCTGCATTACTGGAGA & nt 829-809 & & \\
\hline FNF & CAACACCTAGTAATCATC & nt 2.443.126-2.443.126 & $653 \mathrm{bp}$ & \\
\hline FNR & CGAATGCTAATACCTATA & nt 2.443.761-2.443.778 & & [35] \\
\hline FN-Probe & Cy5-GGCTTCCCCATCGGCATTCC-BHQ & nt 2.443.229-2.443.248 & 604 bp & [34] \\
\hline MHRHF & GAACGGGATGTAGCAATACATTC & nt 18520-18542 & & \\
\hline MHRHR & AGCGGACTGAAGTTGAGCTTCAG & nt 19124-19102 & & \\
\hline Mhr-p37-RT-F & TATCTCATTGACCTTGACTAAC & nt 768.070-768.092 & $89 \mathrm{bp}$ & [15] \\
\hline Mhr-p37-RT-R & ATTTTCGCCAATAGCATTTG & nt 816.070-835.070 & & \\
\hline Mhr-p37-RT-Probe & 6FAM-CATCCTCTTGCTTGACTACTCCTG-MGBNFQ & nt 774.070-796.070 & & \\
\hline
\end{tabular}

Target sequences for $\beta$-globin amplification - PC03/PC04 (110 bp). Target sequences for 16S rRNA of Mollicutes-GPO3/MGSO (270 bp), H. pylori-JW21/JW22 (138 bp), F. nucleatum-FNF/FNR (653 bp), M. hyorhinis-MHRHF/MHRHR (604 bp), and for p37 gene rRNA of M. hyorhinis-Mhr-p37-RT-F/ Mhr-p37-RT-R / Mhr-p37-RTProbe (89 bp)

and M. hominis (ATCC 23114-PG-21) were cultured in SP4 medium ( $\mathrm{pH}$ 7.4), supplemented with glucose or arginine [31]. The strains were obtained from the Mycoplasma Laboratory collection at the Institute of Biomedical Sciences, University of São Paulo, SP, Brazil.

Conventional PCRs were performed to detect $16 \mathrm{~S}$ rRNA of Mollicutes [32], H. pylori [33], and M. hyorhinis [34]. Accordingly, $50 \mathrm{ng} / \mu \mathrm{L}$ of purified DNA was used for each sample, $1 \times$ buffer (Buffer $-10 \times$ Tris $-\mathrm{HCl}$ [ $\mathrm{pH}$ 8.4], $500 \mathrm{mM} \mathrm{KCl}), 0.2 \mathrm{mM}$ of deoxyribonucleotide triphosphate (dNTP), $1.5 \mathrm{mM}$ of $\mathrm{MgCl}_{2}, 50,000 \mathrm{nM}$ of each primer (Table 1), and $1.0 \mathrm{U}$ of Taq DNA polymerase $\left(\right.$ Invitrogen $\left.{ }^{\circledR}\right)$, to achieve a final volume of $25 \mu \mathrm{L}$. For Mollicutes, genus-specific universal primers were used instead. The assays were performed using a Veriti ${ }^{\circledR}$ Thermal Cycler (Applied Biosystems, São Paulo, SP, Brazil). The parameters for each reaction have been previously described [32-34].

Quantitative PCR was used to detect $16 \mathrm{~s}$ rRNA of $F$. nucleatum [35] and p37 of M. hyorhinis [15]. First, mycoplasmas were cultured, and the DNA was extracted according to the manufacturer's instructions. The genomic DNA copy number was then calculated by spectrophotometry. Ten-fold serial dilutions $\left(10^{7}-10\right.$ copies/ $\mu \mathrm{L}$ ) of the mycoplasma DNA standard were prepared and analysed. A standard curve was prepared for each reaction. Samples were analysed in triplicate using a 7300 Real-Time PCR System (Applied Biosystems). The reagents used were as follows: $50 \mathrm{ng} / \mu \mathrm{L}$ of DNA extracted by EM6, $12.5 \mu \mathrm{L}$ of Master Mix (Applied Biosystems), $100 \mu \mathrm{M}$ of each primer (Table 1), and $0.3 \mu \mathrm{M}$ Taqman probe (Table 1); the final volume was $25 \mu \mathrm{L}$. The samples were amplified using StepOne ${ }^{\mathrm{TM}}$ software (Applied Biosystems) with the following cycles: $50{ }^{\circ} \mathrm{C}$ for $2 \mathrm{~min}, 95^{\circ} \mathrm{C}$ for $10 \mathrm{~min}, 40$ cycles of denaturation at $95^{\circ} \mathrm{C}$ for $15 \mathrm{~s}$, and annealing at $55^{\circ} \mathrm{C}$ for $30 \mathrm{~s}$ (to detect $F$. nucleatum DNA) or $57^{\circ} \mathrm{C}$ for $15 \mathrm{~s}$ (to detect $M$. hyorhinis DNA) and extension at $60^{\circ} \mathrm{C}$ for $1 \mathrm{~min}$.

\section{Immunohistochemistry detection}

To confirm whether there was a higher charge of $M$. hyorhinis that was not found by molecular methods, 120 $4-\mu \mathrm{m}$-thick sample sections were assessed for $M$. hyorhinis occurrence using IHC. Si-Ha cells with or without $M$. hyorhinis coinfection were used as positive and negative controls, respectively [36]. Unstained sections of each sample were dewaxed by twice immersing them in xylol baths for $10 \mathrm{~min}$, followed by rehydration in consecutive graduated ethanol baths $\left(99^{\circ}, 96^{\circ}\right.$, and $\left.70^{\circ} \mathrm{GL}\right)$ and distilled water. Peroxidase was blocked with $\mathrm{H}_{2} \mathrm{O}_{2}(10$ vol.) for $10 \mathrm{~min}$, twice, and the samples were then washed with distilled water. Antigenic recovery was carried out in an electric pressure cooker for 15 min using Trilogy ${ }^{\mathrm{TM}}$ Cell Marque solution, followed by washing with distilled water and Tris Buffered Saline (TBS; pH 7.4). The slides were incubated overnight with primary horse polyclonal antibodies against $M$. hyorhinis-7 (NIAID, Bethesda, MD; 1:100) in a darkroom at $4{ }^{\circ} \mathrm{C}$. Next, slides were washed three times using TBS for 5 min, incubated with peroxidase-conjugated rabbit anti-horse IgG (Thermo Fisher Scientific, Waltham, MA, USA) for $30 \mathrm{~min}$, and again washed with TBS. Detection was performed using 
liquid DAB. Sections were counterstained with haematoxylin. Immunohistochemical expression was observed by optical microscopy $(40 \times)$, with 100 nuclei counted in 10 fields; every distinct brown stain was considered positive [37].

\section{Histopathological analyses}

A trained pathologist microscopically analysed H\&Estained slides. Specimens were examined and staged according to the guidelines of the Joint American Cancer Commission/International Union against Cancer/Classification of Malignant Tumours [38]. Metastatic disease was confirmed when, according to clinical records, lesions were detected in other organs or lymph nodes. The histological type of the tumour was classified as intestinal or diffuse [3].

\section{Statistical analysis}

Data analysis was performed using SPSS 20.0 (IBM, Corp., Armonk, NY, US). Categorical variables are presented as frequencies and percentages. We used the logistic regression model and odds ratio (OR) and calculated the respective $95 \%$ confidence intervals (CI). Variable selection was conducted in a stepwise manner and the unadjusted and adjusted OR were considered in the final model. The goodness of fit was verified by a Hosmer-Lemeshow test. Only significant variables $(P<0.05)$ were used in the final model unless the variable was biologically relevant. A standard Chi-square test was used to assess the strength of association between the presence of a study microorganism and certain clinicopathological characteristics. The non-parametric Mann-Whitney $\mathrm{U}$ test was used to evaluate the microbial load of $M$. hyorhinis in the case and control groups (positive and negative), using GraphPad Prism version 5.01 (GraphPad Software, Inc., La Jolla, CA, USA).

\section{Results}

\section{DNA extraction time, yield, and purity}

Dewaxing of FFPEs using xylol required 30 to $90 \mathrm{~min}$ compared to $1 \mathrm{~min}$ with mineral oil. The phenol-chloroform (EM1, EM2, and EM3) extractions were more laborious and time-consuming than those performed using alkaline buffer (EM4) and commercial kits (EM5 and EM6) (Table 2). Table 2 also presents the mean values of the total amount and purity of extracted DNA. EM1, EM2, and EM6 showed the best results according to DNA quantity $(2.12,2.10$, and 2.09 , respectively) and purity ratios $(1.91,1.92$, and 1.98 , respectively). Based on our evaluation, all 120 FFPE samples were dewaxed with mineral oil and DNA was extracted using EM6.

DNA extraction was validated by qualitative confirmation using PCR for the endogenous housekeeping control
Table 2 Evaluation of purity and amount of DNA extracted from fragments of FFPE gastric tissue samples

\begin{tabular}{llll}
\hline DNA extraction method & $\mathbf{2 6 0 / 2 3 0 *}$ & $\mathbf{2 6 0 / 2 8 0 *}$ & DNA (ng/ $\mathbf{u L})$ \\
\hline EM1 & & & \\
Xylol dewaxing material & 2.12 & 1.91 & 2.507 \\
Non-dewaxing material & 2.35 & 1.75 & 47 \\
EM2 & & & \\
Xylol dewaxing material & 2.10 & 1.92 & 475 \\
Non-dewaxing material & 2.47 & 1.66 & 168 \\
EM3 & & & \\
Xylol dewaxing material & 1.82 & 1.59 & 99 \\
Non-dewaxing material & 1.59 & 1.56 & 53 \\
EM4 & & & \\
Xylol dewaxing material & 0.38 & 1.19 & 800 \\
Non-dewaxing material & 0.38 & 1.27 & 431 \\
EM5 & & & \\
Xylol dewaxing material & 1.38 & 1.81 & 243 \\
Mineral oil dewaxing material & 1.24 & 1.94 & 112 \\
Non-dewaxing material & 1.69 & 2.06 & 183 \\
EM6 & & & \\
Xylol dewaxing material & 2.50 & 2.60 & 21 \\
Mineral oil dewaxing material & 2.09 & 1.98 & 82 \\
Non-dewaxing material & 2.96 & 2.78 & 16 \\
\hline Thew & & & \\
\hline
\end{tabular}

*The wavelengths of 260/230 nm (ratio: 2.0-2.2) and 260/280 nm (ratio: 1.7-2.0) were considered acceptable for evaluation

In the 260/230 nm wavelength, EM1 and EM2 extraction methods and EM6 dewaxed with mineral oil show good DNA extraction. EM3, EM4, and EM5 extractions show low absorbance values, indicating contamination of salts (e.g. EDTA). At 260/280 nm, EM1, EM2 (dewaxed), EM5, and EM6 (dewaxed with mineral oil) present sufficient DNA purity. EM2 (Non-dewaxing material), EM3, EM4, and EM6 (xylol dewaxing material and non-dewaxing material) present insufficient DNA purity, indicating protein contamination and other organic compounds

$\beta$-globin, with primers PC03/PC04 (110 bp). This reaction generates a small amplification product and is more suitable for DNA extracted from paraffin [22]. In total, 113 samples were positive for $\beta$-globin (case group, 73; control group, 40).

DNA detection of Mollicutes, M. hyorhinis, H. pylori, and $F$. nucleatum according to patient gender and age

Considering both the case and control groups, the mean patient age was 60 years $(n=120$, Table 3$)$, with a majority of male subjects $(\sim 60 \%)$. The case group consisted of predominantly males $(\sim 74 \%)$ and the control group of females $(70 \%)$. Males had a fivefold higher risk $(\mathrm{CI}=1.647-17.239)$ of developing gastric cancer $(P=0.004)$. Based on the median age, patients above 59 years of age had a 32 -fold greater risk $(\mathrm{CI}=8.112$ $129.376)$ of developing gastric cancer $(P=0.001)$. Table 3 also presents the presence and absence of our bacterial study species, PCR was performed to detect the DNA of Mollicutes in all the samples positive for the $\beta$-globin 
Table 3 Relationship between gender, age, and detection of microorganisms

\begin{tabular}{|c|c|c|c|c|c|c|c|}
\hline \multirow[t]{2}{*}{ Variables } & \multirow{2}{*}{$\begin{array}{l}\text { Case } \\
n=80(\%)\end{array}$} & \multirow{2}{*}{$\begin{array}{l}\text { Control } \\
n=40(\%)\end{array}$} & \multirow{2}{*}{$\begin{array}{l}\text { Total } \\
n=120(\%)\end{array}$} & \multicolumn{2}{|l|}{ OR (Crude) } & \multicolumn{2}{|c|}{ OR (Adjusted) ${ }^{a}$} \\
\hline & & & & $\begin{array}{l}P \\
\text { (Wald's Test) }\end{array}$ & $\begin{array}{l}\text { OR } \\
(95 \% \mathrm{Cl})\end{array}$ & $\begin{array}{l}P \\
\text { (Wald's Test) }\end{array}$ & $\begin{array}{l}\text { OR } \\
(95 \% \mathrm{Cl})\end{array}$ \\
\hline \multicolumn{8}{|l|}{ Gender } \\
\hline Male & $59(73.8)$ & $12(30.0)$ & $71(59.2)$ & 0.001 & 6.556 & 0.005 & 5.328 \\
\hline Female & $21(26.2)$ & $28(70.0)$ & $49(40.8)$ & & $(2.831-15.183)$ & & $(1.647-17.239)$ \\
\hline \multicolumn{8}{|l|}{ Age } \\
\hline$\geq 59$ years & $62(77.5)$ & $4(10.0)$ & $66(55.0)$ & 0.001 & 31.000 & 0.000 & 32.395 \\
\hline$\leq 58$ years & $18(22.5)$ & $36(90.0)$ & $54(45.0)$ & & $(9.731-98.753)$ & & $(8.112-129.376)$ \\
\hline \multicolumn{8}{|c|}{ Mollicutes (PCR) } \\
\hline Positive & $9(12.3)^{b}$ & $1(2.5)$ & $10(8.8)^{c}$ & $0.563^{c}$ & 2.345 & $0.622^{c}$ & $\begin{array}{l}2.294 \\
(0.084-62.384)^{c}\end{array}$ \\
\hline Negative & $64(87.7)^{b}$ & $39(97.5)$ & $103(91.2)^{c}$ & & $(0.131-41.962)^{c}$ & & \\
\hline \multicolumn{8}{|c|}{ H. pylori (PCR) } \\
\hline Positive & $6(8.2)^{b}$ & $9(22.5)$ & $15(13.3)^{c}$ & $0.763^{c}$ & 0.671 & $0.978^{c}$ & 1.046 \\
\hline Negative & $67(91.3)^{b}$ & $31(77.5)$ & $98(86.7)^{c}$ & & $(0.050-8.946)^{c}$ & & $(0.042-25.885)^{c}$ \\
\hline \multicolumn{8}{|c|}{ F. nucleatum (qPCR) } \\
\hline Positive & $19(26.0)^{b}$ & $1(2.5)$ & $20(16.7)^{c}$ & $0.080^{c}$ & 0.353 & $0.023^{c}$ & 0.130 \\
\hline Negative & $54(74.0)^{b}$ & $39(97.5)$ & $100(83.3)^{c}$ & & $(0.353-0.110)^{c}$ & & $(0.022-0.756)^{c}$ \\
\hline \multicolumn{8}{|c|}{ M. hyorhinis (qPCR) } \\
\hline Positive & $8(11.0)^{b}$ & $2(5.0)$ & $10(8.8)^{c}$ & $0.021^{c}$ & 11.357 & $0.045^{c}$ & 10.562 \\
\hline Negative & $65(89.0)^{b}$ & $38(95.0)$ & $103(91.2)^{c}$ & & $(1.1443-89.397)^{c}$ & & \\
\hline
\end{tabular}

Positive-Detection of expected DNA product. Negative-Absence of expected DNA product.

a adjusted for $M$. hyorhinis and Mollicutes. The goodness of the adjustment was evaluated by the Hosmer-Lemeshow test $(P=0.914)$

b Considering the case group, $\mathrm{n}=73$

c Considering $\mathrm{n}=113$ patients

$\mathrm{OR}$, odds ratio; $\mathrm{Cl}$, confidence interval; $\mathrm{qPCR}$, quantitative polymerase chain reaction

gene $(\mathrm{n}=113) ; 10$ samples were found to be positive for Mollicutes (8.8\%), nine from patients with cancer $(12.3 \%)$ and one from a healthy patient $(2.5 \%)$. The presence of Mollicutes did not affect the development of gastric cancer, but was associated with a twofold higher cancer risk factor compared with the control group.

For $H$. pylori, 15 samples were positive (13.3\%): six from patients with cancer $(8.2 \%)$ and nine from healthy patients $(22.5 \%)$. The presence of $H$. pylori did not affect the cancer risk factor in the case group. H. pylori was strongly associated with the control group $(P=0.023)$, which suggests that the stomach becomes a favourable environment for $H$. pylori infection after bariatric surgery $(\mathrm{OR}=0.130$, CI $95 \%=0.022-0.756)$. For $F$. nucleatum, 20 samples were found to be positive (16.7\%): 19 from patients with cancer $(26.0 \%)$ and one from a healthy patient (2.5\%) (Table 3). The prevalence of F. nucleatum in the case group was significant $(P=0.045))$ and was associated with an 11-fold increase in the risk of developing gastric cancer (CI 95\% $=1.057-105.521)$.

None of the samples tested positive for M. hyorhinis when using EM6 (data not shown). However, based on the qPCR results, eight samples from the case group
(11.0\%) and two samples from the control group (5.0\%) were positive for M. hyorhinis (Table 3).

By employing a quantitative real-time PCR method, it was possible to quantify DNA as well as the microorganism load, represented as colony-forming units (CFU)/ $\mathrm{mL}$. The average loads of positive samples were approximately $10^{0}$ to $10^{8} \mathrm{CFU} / \mathrm{mL}$ of $M$. hyorhinis (Fig. 1). In the case group, the mean load of $M$. hyorhinis was $4.44 \times 10^{7} \mathrm{CFU} / \mathrm{mL}\left(\mathrm{SD} \pm 6.85 \times 10^{7}\right.$, minimum and maximum load of $0.14-1.68 \times 10^{8}$ ) and in the control group the mean load was $38.86 \mathrm{CFU} / \mathrm{mL}(\mathrm{SD} \pm 35.87$, minimum and maximum load of 0.0-66.84). We could not detect a significant difference in microbial loads between the groups. There was no association between the OR (epidemiological association between outcome variables [patients with cancer $\times$ patients without cancer]) and $M$. hyorhinis detection rates (presence $\times$ absence) $(\mathrm{OR}=0.671 ; \mathrm{CI}=0.050-8.946$; Table 3$)$.

\section{Immunohistochemical detection of $M$. hyorhinis in FFPE samples of gastric tissues}

IHC was used to confirm the presence of $M$. hyorhinis in 120 samples prepared on slides using anti-M. hyorhinis 

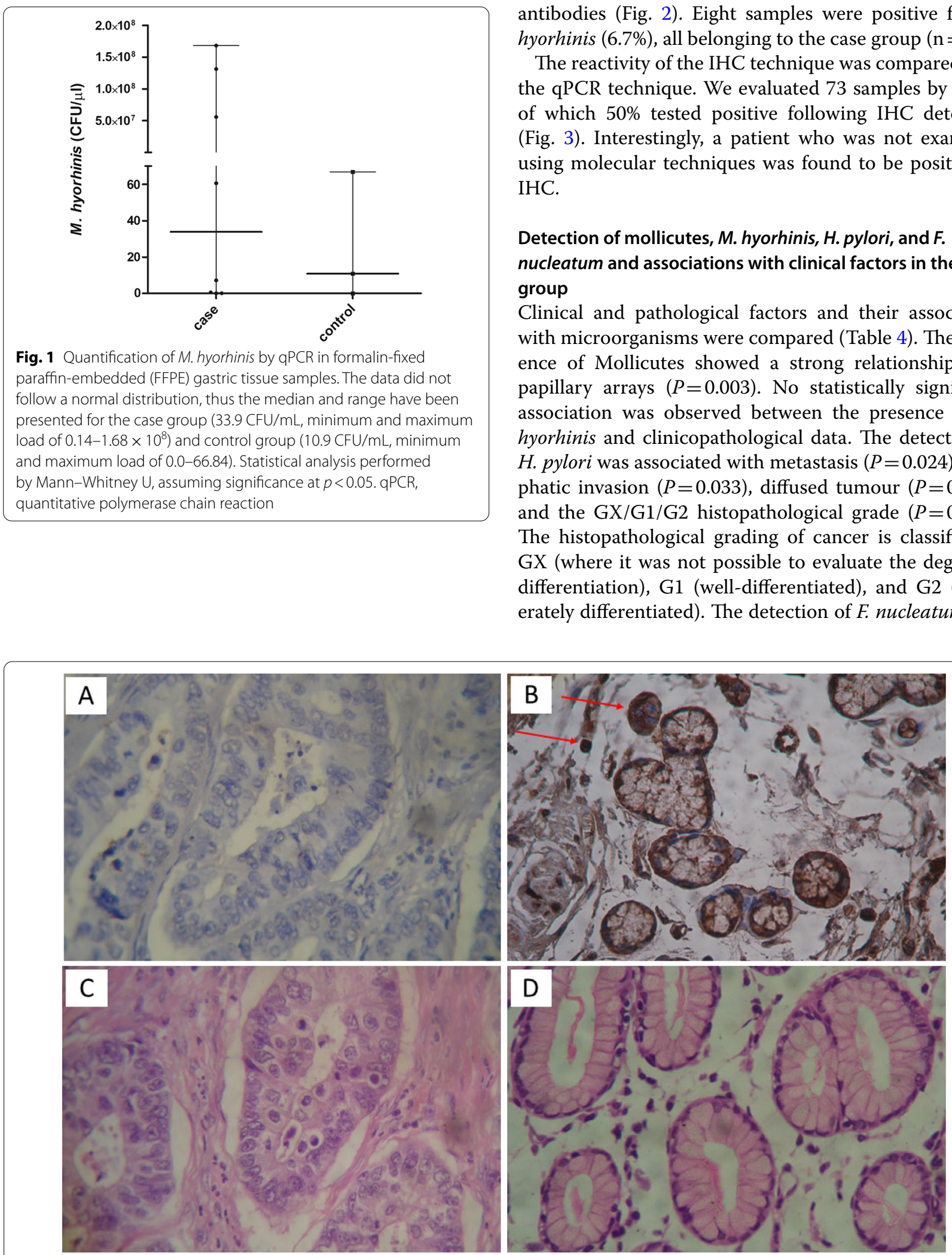

Fig. 2 - Micromorphology of immunohistochemical (IHC) examination of gastric tissue treated with antibodies against M. hyorhinis protein p37. A Unmarked (negative). B Strong marking (positive). Arrows indicate the positive immunoreactivity for M. hyorhinis, with well-coloured cytoplasm. C and $\mathbf{D}$ haematoxylin-eosin (H\&E)-stained sections. Gastric adenocarcinoma at $40 \times$ magnification antibodies (Fig. 2). Eight samples were positive for $M$. hyorhinis (6.7\%), all belonging to the case group $(\mathrm{n}=80)$.

The reactivity of the IHC technique was compared with the qPCR technique. We evaluated 73 samples by qPCR of which 50\% tested positive following IHC detection (Fig. 3). Interestingly, a patient who was not examined using molecular techniques was found to be positive by IHC.

\section{Detection of mollicutes, $M$. hyorhinis, $H$. pylori, and $F$. nucleatum and associations with clinical factors in the case group}

Clinical and pathological factors and their association with microorganisms were compared (Table 4). The presence of Mollicutes showed a strong relationship with papillary arrays $(P=0.003)$. No statistically significant association was observed between the presence of $M$. hyorhinis and clinicopathological data. The detection of $H$. pylori was associated with metastasis $(P=0.024)$, lymphatic invasion $(P=0.033)$, diffused tumour $(P=0.028)$, and the $\mathrm{GX} / \mathrm{G} 1 / \mathrm{G} 2$ histopathological grade $(P=0.008)$. The histopathological grading of cancer is classified as GX (where it was not possible to evaluate the degree of differentiation), G1 (well-differentiated), and G2 (moderately differentiated). The detection of $F$. nucleatum was

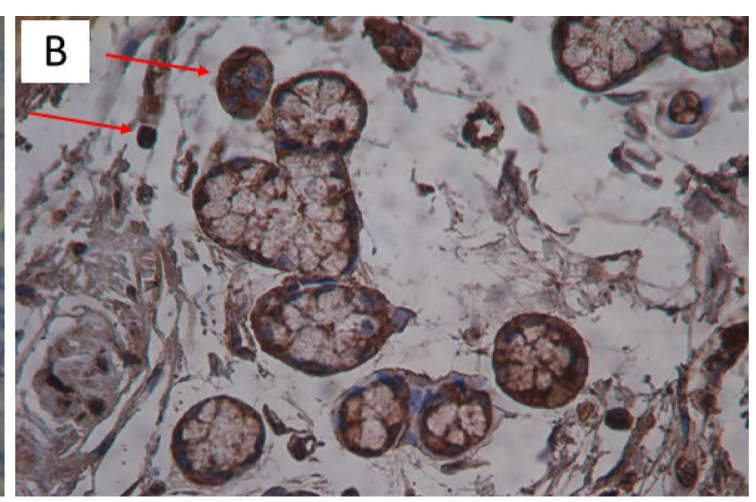




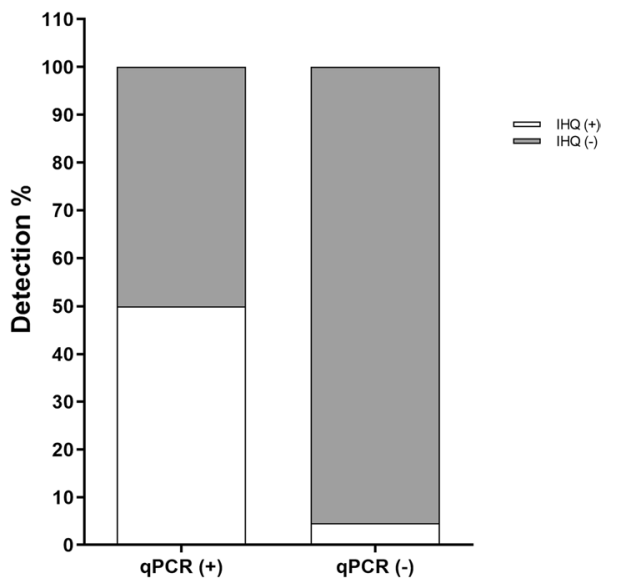

Fig. 3 Detection of M. hyorhinis by $\mathrm{IHC}$ and $\mathrm{qPCR}$ in gastric cancer tissues. In the case group $(n=73)$, eight patients were found to be positive for $M$. hyorhinis by qPCR and, among these, four were found to be positive by IHC detection (50\%). In total, 65 samples were negative for $M$. hyorhinis by $\mathrm{qPCR}$; among these, three were positive for M. hyorhinis by $\mathrm{IHC}$ detection (4.6\%). qPCR, quantitative polymerase chain reaction

associated with advanced age $>59(P=0.030)$ and large tumour fragments $>4 \mathrm{~cm}(P=0.053)$.

\section{Coinfection profile and detection rate of mollicutes, $M$. hyorhinis, F. nucleatum, and $H$. pylori in the case and control groups}

There was no difference in the abundance of Mollicutes, $M$. hyorhinis, or $F$. nucleatum between the case and controls groups $(P=0.117, P=0.140$, and $P=0.214$, respectively). However, the abundance of $H$. pylori differed significantly between the case and control groups $(P=0.008)$. Coinfection profiles, the detection of two or more study microorganisms in the same clinical sample, were analysed in the two groups (Fig. 4). In the case group samples that were positive for Mollicutes $(\mathrm{n}=73)$, six were positive for $M$. hyorhinis according to $\mathrm{qPCR}$ and IHC, respectively. The only sample positive for Mollicutes in the control group was negative for $M$. hyorhinis according to PCR. Mollicutes, M. hyorhinis, and $F$. nucleatum showed coinfection in two samples of the case group alone.

H. pylori and F. nucleatum showed coinfection only in one sample of the case group. H. pylori showed no coinfection with Mollicutes, but in the control group $(\mathrm{n}=40)$ there was coinfection with $M$. hyorhinis and H. pylori in one patient. Overall, $56.25 \%$ of the case group samples and $70.00 \%$ of the control group samples were negative for any of the study microorganisms. The detection of $H$. pylori was higher in the control group, likely due to the favourable conditions created by congestion in the gastric wall that promotes acid secretion and inflammation. There was a significant difference in microorganism abundance between the groups $(P=0.001)$. Unlike $H$. pylori, the detection frequency of Mollicutes, F. nucleatum, and M. hyorhinis were considerably higher in the case group.

\section{Discussion}

Cancer has been a major research focus worldwide, with diverse risk factors associated with its development. In Brazil, stomach cancer mortality rates are male-biased, with the highest rates of occurrence observed in the Northeast region [2]. Brazil and other developing countries are disproportionately affected by infectious agents that are considered risk factors for developing cervical, liver, and stomach cancer [1]. Research into $M$. hyorhinis gained widespread momentum after its detection in human carcinomas and can potentially induce cell migration and metastasis, correlating with changes in phenotype and cellular karyotype. This change in cellular behaviour was associated with protein $\mathrm{p} 37$, present in its cell membrane $[18,39]$. In general, mycoplasmas have been associated with malignant transformation in cell cultures and immortalisation of cells, promoting cell migration/invasion in immunosuppressed mice $[4,40]$. Likewise, $F$. nucleatum has also been reported to cause tumour progression in immunosuppressed mice subjected to xenografts of patient-derived tumours [41].

The storage of tissues in paraffin blocks is convenient for transport, and also allows for retrospective examinations that could provide valuable information in epidemiology [22]. However, the recovery of nucleic acids in this type of material is difficult and with no methodological consensus in the literature with regards to optimal procedures. In the present study, six methods for DNA extraction from gastric fragments in FFPE blocks were compared for the detection of Mollicutes, M. hyorhinis, F. nucleatum, and H. pylori. Mineral oil dewaxing and commercial kits demonstrated the desired preferences, based on elapsed time, absence of toxic organic solvent reagents (such as phenol), and quality of target DNA after PCR [25, 27, 42]. Although extraction kits obtained a smaller amount of DNA, they allowed for a more efficient detection of targeted DNA, as residues that inhibit PCR efficacy are eliminated, thus reducing the possibility of sample contamination [43].

The DNA extraction methodology that demonstrated greater purity and recovery of nucleic acids was used for detecting the $\beta$-globin gene with $\mathrm{PC} 03 / \mathrm{PC} 04$ primers, which was identified in 113 gastric tissue samples. FFPE samples are usually exposed to formaldehyde for a prolonged period of time, which modifies protein 


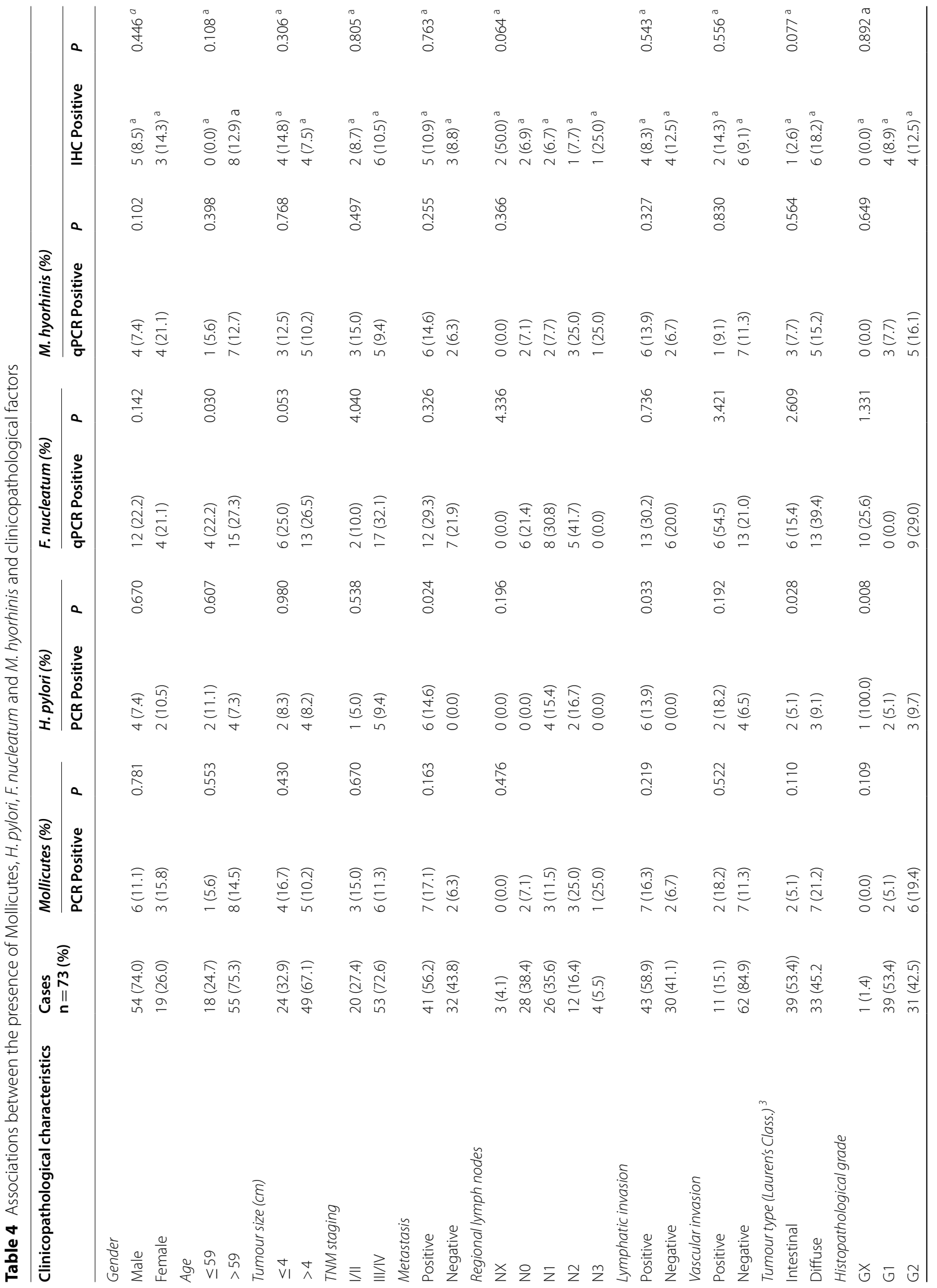




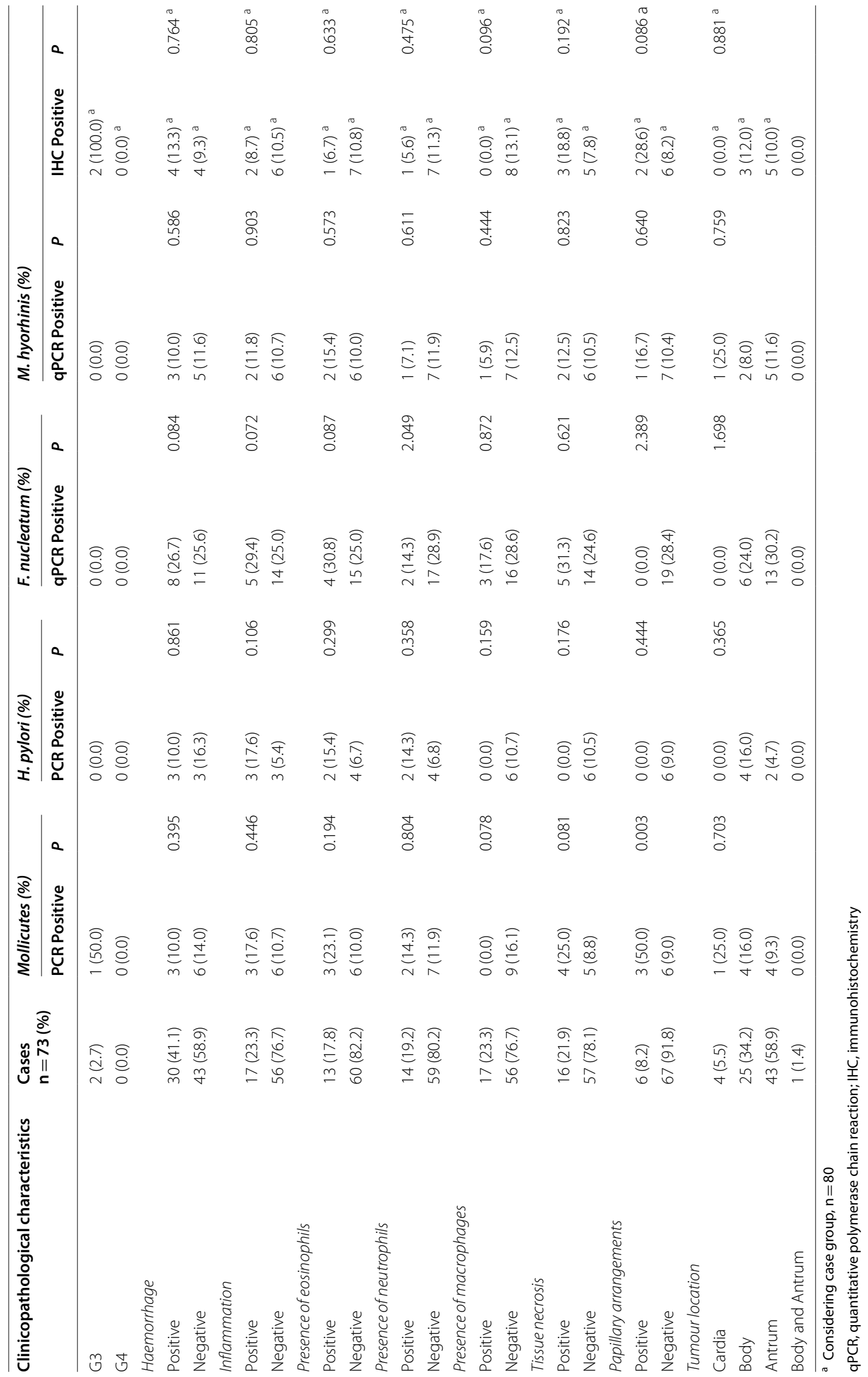




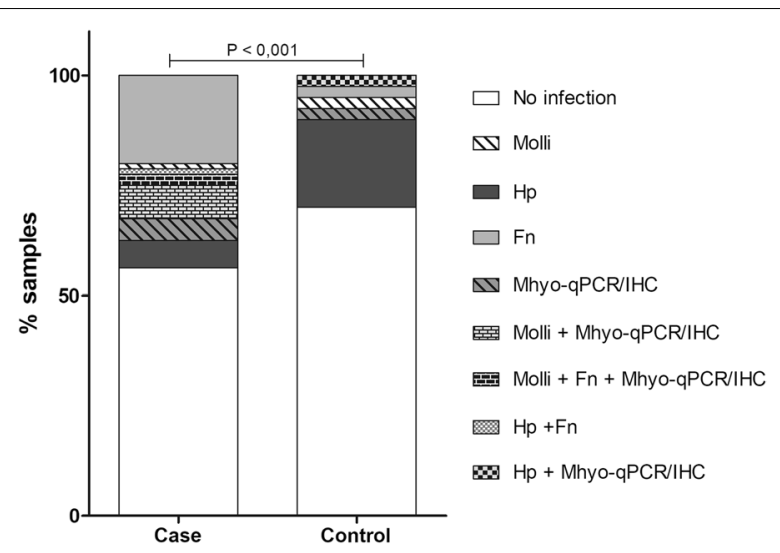

Fig. 4 Detection rate of Mollicutes (PCR), He. pylori (PCR), F. nucleatum (qPCR), and $M$. hyorhinis ( $\mathrm{PPCR}$ and $\mathrm{IHC}$ ), from gastric tissue. The diagonal lines on the white background represent Mollicutes (Molli) in the case and control group (1.25\% and $2.50 \%$, respectively). Dark-grey represents H. pylori (Hp) in the case and control group (6.25\% and $20.00 \%$, respectively). Light-grey represents F. nucleatum (Fn) in the case and control group (20.00\% and $2.50 \%$, respectively). The diagonal lines on the grey background represent $M$. hyorhinis (Mhyo-qPCR/IHC) in the case and control group (5.00\% and 2.50\%, respectively). Coinfection of the case samples: $7.50 \%$ with Mollicutes and M. hyorhinis (brick with white background), $2.50 \%$ of Mollicutes (M. hyorhinis) and F. nucleatum (brick with black background), and $1.25 \%$ of F. nucleatum and H. pylori (light-grey squares). In the control samples, only one coinfection of $M$. hyorhinis and $H$. pylori was observed (2.50\%, dark-grey squares). qPCR, quantitative polymerase chain reaction; $I \mathrm{HC}$, immunohistochemistry. Mann Whitney, assuming $p$-value $\leq 0.05$

morphology and DNA stability and, additionally, causes DNA fragmentation; hence, successful detection of housekeeping genes increases with smaller products owing to the increased possibility of amplifying fragmented DNA [22, 29, 33].

Mollicutes were detected in only $8.8 \%$ of the samples (10/120): $12.3 \%$ of the case group (9/73) and $2.5 \%$ of the control group (1/40), indicating a low prevalence of these microorganisms in FFPEs. This low detection rate does not rule out the possibility that the Mollicutes contribute to cellular changes in cancer, since detection can be affected by the host's immune response. The use of antibiotics to treat an early-stage $H$. pylori infection can also suppress Mollicutes, and $H$. pylori itself is a strong competitor that can inhibit the proliferation of other microorganisms [44, 45]. In the present study, Mollicutes were not detected in individuals with $H$. pylori and gastric cancer, though this could be an artefact of small sample size.

Intestinal and diffuse gastric tumours with similar clinical characteristics have been associated with greater metastatic potential, rapid tumour progression, and poor prognoses, which is induced by chromosomal aberrations and papillary tumours $[40,41]$. The presence of
Mollicutes was predominant in the diffuse type tumour, in moderately differentiated tumours (G2), and in patients with metastases. Although this association was not significant, Mycoplasma are considered opportunistic pathogens and cytogenetic modifiers [42, 43], with the ability to persist in the host for a prolonged period of time, favouring the gradual dysregulation of cell biology [46].

The Mollicutes showed a strong association with papillary tissue arrays (8.2\% of patients). Previous research has also found Mollicutes associated with polyp formations in colon and mycoplasma infections [16]. Research suggests that Mycoplasma is able to stimulate cell transformation [11, 46]; production of lipid-associated membrane proteins (LAMPs) or macrophage-activating lipopeptide-2 (MALP-2), which induce the MyD88 pathway and NF- $\mathrm{kB}$ activation through toll-like receptors 1 , 2 , and 6 [47, 48]; induce major inflammatory events via nitric oxide synthase (iNOS) [48, 49]. Cell aberrations induced during Mycoplasma infection may also originate from their capacity to block host DNA repair, as seen in in vitro assays with the protein DnaK, isolated from $M$. fermentans. This chaperone binds to poly (ADP-ribose) polymerase (PARP-1) or in the p53 regulator, impairing the host's DNA repair capacity and leading to p53 silencing [50]. Moreover, p53 silencing may stimulate chromosomal instability and cell transformation [40,51]. Blocking of the host's DNA repair capacity occurs during $H$. pylori infection, which induces NF-kB expression, leading to chronic inflammation and atrophic gastritis, metaplasia, and dysplasia [20,52].

Persistent $H$. pylori infection has been classified as carcinogenic to humans (Group 1) by the International Agency for Research on Cancer [53]. In the present study, H. pylori infection was detected in control individuals, which can be expected in a stomach microenvironment altered by surgery and can trigger the development of ulcers, making this site even more favourable for the establishment of this bacteria $[54,55]$. The clinical aspects of infection vary depending on location, host susceptibility, bacterial strain (not all strains of $H$. pylori are oncogenic), environmental influence, and host habits [56]. Approximately $10 \%$ to $15 \%$ of individuals with $H$. pylori infection may develop severe inflammation and peptic ulcers [57], as well as gastric adenocarcinoma (1-3\%) or lymphoma $(0.1 \%)$ [58].

In our study, $H$. pylori was significantly associated with metastasis $(P=0.024)$ and lymphatic invasion $(P=0.033)$. In a pervious study, H. pylori has been associated with the expression of CagA, the most important virulence factor of $H$. pylori, which induces the robust activation of SHP-2 and ERK. CagA also promotes tumorigenesis by inducing gastric epithelial cell 
mobility and proliferation [59]. In the present study, $H$. pylori was located in non-cardia regions of the stomach, similar to previous studies [60]. The presence of H. pylori was marginally associated with differentiated (G2) $(P=0.008)$ and diffused type $(P=0.028)$ tumours. These tumour phenotypes have also been correlated with $H$. pylori in a previous study [61]. Moreover, $H$. pylori has also been associated with the dysregulation of pepsinogen I (PG1) and pepsinogen 2 (PG2) [62], decreased gastric glands [63], and expression of interleukin (IL)-10, leading to an anti-inflammatory response that attenuates the immune system's response [64].

The silencing of the human immune response against tumorigenesis has also been reported during $F$. nucleatum infection, that contributes to carcinogenesis by inducing preneoplastic conditions [9]. Although F. nucleatum is predominant in colorectal tumours, it is also well established in gastric tumour tissues, where it is associated with poor survival rates by promoting metastasis and diffuse-type tumour progression [65]. In the present study, $F$. nucleatum was predominant in the stomach and body and antrum regions in patients with metastasis and lymphatic invasion, similar to $H$. pylori. However, $H$. pylori is reportedly an initiator of the Correa cascade and F. nucleatum is not related to chronic gastritis, so rather than being an initiator, F. nucleatum may be involved in the final stages of the classical Correa cascade [65].

Diffuse-type tumours are strongly associated with E-cadherin dysregulation. It is well known that $F$. nucleatum promotes carcinogenesis by linking FadA to E-cadherin, activating $\beta$-catenin and the Wnt pathway, inducing the expression of several oncogenic properties [66]. FadA expression, in addition to being associated with E-cadherin expression, is also strongly associated with host DNA damage, cell proliferation, chk2 expression, S-phase cells, and an increase in tumour size [66]. In our study, the presence of $F$. nucleatum was significant at tumour size $>4 \mathrm{~cm}(P=0.053)$. Tumour size and TNM stage III/IV have also been associated with $F$. nucleatum in other studies [67]. In addition to FadA mechanisms, TLR4 activation by $F$. nucleatum' LPS can plausible lead to the activation of Myd88 and NF- $\mathrm{kB}$, which leads to oncogenic overexpression of miR21, resulting in dysregulated growth and infiltration of tumour tissue. According to our results, the presence of $F$. nucleatum was significant in patients $>59$ years of age $(P=0.30)$, which could be due to lower global long interspersed element-1 (LINE-1) DNA methylation [65], and epigenetic silencing of the MLH1 repair protein caused by cytokine modulation (e.g., IL-6 e TNF) [68]. This suggest that F. nucleatum may be associated with epigenetic alterations, such as global DNA hypomethylation. Similarly, M. hyorhinis has been described as an intracellular agent that could modulate the host epigenetic machinery through nucleomodulins [69].

A possible mechanism of tumour pathogenicity of $M$. hyorhinis may be due to the activity of its methyltransferases, in which three types have already been described: Mhy1 and Mhy2, which promote methylation of CG, and Mhy3, which acts on GATC sites leading to aberrant methylation patterns in its entire genome [69]. Hypermethylation of the GATC site is related to the silencing of specific genes, such as APC, TP53, BRCA2, KRAS, PTEN, $S M A D 4$, and $V E G F C$. GATC methylation is uncommon in human cells and may emerge during $M$. hyorhinis infection, suggesting a new type of epigenetic infectiondependent marker [69]. Other mycoplasmas, such as $M$. penetrans and M. pulmonis, can also methylate GC sites, indicating that methylation may be a significant factor for these bacteria to adapt and survive in the host [70]. Aberrant methylation frequently contributes to malignant cellular phenotypes [4]. Furthermore, $H$. pylori infection can induce the aberrant methylation of genes such as tp53 and the Wnt pathway-factors strongly associated with gastric adenocarcinoma development [71]. Similar to H. pylori, M. hyorhinis was more biased toward the G2 tumour and diffused type, unlike what has been found in previous studies [17], and was localised mainly in the stomach body. This adenocarcinoma mainly affects older adults and can lead to a permanent inflammatory process and the gradual alteration of cells [64].

$M$. hyorhinis could not be detected by conventional PCR, probably because its PCR product was too large and DNA from paraffin specimens tends to come in small fragments [27]. According to qPCR analysis, $11.0 \%$ of the case group samples were positive for M. hyorhinis; among these, six were paired with the positive Mollicutes PCRs. The association of $M$. hyorhinis with gastric cancer development has previously been reported in studies showing that $50 \%$ of FFPE gastric cancer samples were positive for M. hyorhinis by PCR or IHC detection targeting p37 $[16,72]$. qPCR also detected the DNA of $M$. hyorhinis in $5.0 \%$ of the samples from the control group. However, the samples that were positive for $M$. hyorhinis did not match the positive samples for Mollicutes. Indeed, other species of the class Mollicutes have been described in samples of gastric disease [11].

The detection of $M$. hyorhinis by the IHC revealed that $\sim 10 \%$ of the samples in the case group were positive. In the case group, 8 samples positive for $M$. hyorhinis were detected, 4 of which were detected by both the IHC and qPCR methods. In the control group, two samples were positive for $M$. hyorhinis and were detected by qPCR, whereas IHC failed to detect the protein p37. The IHC could be a better method for target detection when 
considering that the formaldehyde in blocks may damage the $M$. hyorhinis DNA composed of approximately $74 \%$ $\mathrm{A}+\mathrm{T}$ bases, while formalin preserves the protein morphology and inactivates proteolytic enzymes that favour the IHC methodology. Nevertheless, the qPCR method showed a higher detection sensitivity, indicating that the minimal amounts of DNA remain intact even under the action of chemical solutions and storage time; truncated proteins can also be difficult to detect by IHC [73]. These differences between tests have been observed in other studies [37]. The samples positive for $M$. hyorhinis by IHC were associated with gastric cancer risk, as reported in previous investigations [16].

If the detection of M. hyorhinis by IHC and qPCR was possible, then we assume that the assessed individuals were exposed to this microorganism at some level. Our current understanding of how $M$. hyorhinis infects humans remains poor, though pathogenic and environmental factors undoubtedly play a role. Indeed, the opportunistic character of Mollicutes, mainly antigenic variation, oxidative stress induction, and a limited host immune response, allow these bacteria to establish permanent infections and settle in different ecological niches [46]. Several Mollicute species are typically found in animals but have been detected in humans without symptoms of disease, though some species may cause disease, particularly in immunocompromised individuals [10].

In the present study, $M$. hyorhinis was detected in gastric samples belonging to 59 patients, presenting tumour invasion (TNM stage III/IV) and lymphatic invasion. The $M$. hyorhinis $\mathrm{p} 37$ membrane protein is described to interact with TLR4 and induce the rapid expression of several genes linked to inflammation, in addition to promoting the progression of cancer toward metastasis, as it facilitates PI3k phosphorylation and activation of the PI3k-AKT pathway [21, 46]. The p37 protein induces the expression of HRAS (known capacity in mycoplasmas), resulting in PI3k phosphorylation, which regulates cell motility [74]. In prostate cells, p37 has the ability to induce matrix metalloproteinase-2 (MMP-2) super activity and thereby increases EGFR phosphorylation, this can potentially result in cells acquiring a greater potential for dissemination, thus inducing metastasis [46]. This indicates that the ability of these microorganisms to colonise and promote inflammation in the gastric environment is strongly associated with the modulation of mechanisms expressed in local cells.

\section{Conclusion}

This study was limited to exploring the clinicopathological characteristics of gastric tumour tissues and their associations with microorganisms, opening doors for the exploration of in vitro methods to analyse which microbial factors induce different cell signalling pathways, metabolic changes, or extracellular responses in cell matrix models.

Collectively, our findings indicate that FFPE tissue samples improved our previous understanding with regards to the strength of association of Mollicutes, $M$. hyorhinis, F. nucleatum, and $H$. pylori in gastric cancer. H. pylori alone may not lead to all the changes necessary for neoplastic development, but the complex feedback of the microbiotic community can contribute to the conditions of the disease. F. nucleatum is frequently found in biopsies of patients with gastric cancer, but there are still many unanswered questions about its role in the development of the disease.

Mollicutes are often underestimated as potential factors that drive diverse pathological aspects of certain diseases, but the association of mollicutes with the formation of papillary arrays demonstrates its importance in terms of observed malignant phenotypes. Mollicutes of animal origin represent a wide field of classical opportunistic bacteria capable of inducing human disturbances. The detection of $M$. hyorhinis in Brazilian populations with stomach cancer is an important finding. Therefore, this study contributes to a better understanding of the role of these bacteria in the development of gastric cancer and its malignant transformation.

\section{Abbreviations}

BA: Bahia; FFPE: Formalin-fixed paraffin-embedded; IHC: Immunohistochemical; H\&E: Haematoxylin-eosin; EM: Extraction method; PK: Proteinase K; CFU: Colony-forming unit; GX: Not possible to evaluate the degree of tumour differentiation; G1:Tumour well-differentiated; G2: Tumour moderately differentiated; IARC: International Agency for Research on Cancer.

\section{Acknowledgements}

The authors would like to acknowledge the Pathological Anatomy and Cytopathology Service for their assistance with samples and pathological analyses of patient data. Jim Hesson revised the manuscript (https://www.academicen glishsolutions.com).

\section{Authors' contributions}

CNA: conceptualisation, data analysis, designing all methodology, investigation during laboratory work, writing the original draft, and reviewing the final manuscript. ATA: data analysis, designing molecular biology methodology, and performing laboratory investigations. MSB: data analysis, designing immunological tests, performing laboratory investigations. JCPLA: interpretation of immunohistochemistry results, performing laboratory investigations. GBC: conceptualisation, methodology review, and reviewing the final manuscript. CLM: interpretation of histopathology results, methodology review, and reviewing the final manuscript. LMM: conceptualisation, methodology review, and reviewing the final manuscript. JT: conceptualisation, methodology review, and reviewing the final manuscript. All authors have read and approved the manuscript.

\section{Funding}

This work was supported by grants from the São Paulo Research Foundation (FAPESP) (Grant Number 2014/05071-6) and Coordenação de Aperfeiçoamento de Pessoal de Nível Superior-Brasil (CAPES) (Finance Code 
001). The funders played no role in the design, interpretation of results, or conclusion of the study.

\section{Availability of data and materials}

All data generated or analysed during this study are included in this article. The other raw datasets used and/or analysed in this study will be made available upon reasonable request to the corresponding author.

\section{Declarations}

\section{Ethics approval}

Ethical approval was granted by the ICB Human Research Ethics Committee (CEPSH), São Paulo, Brazil (1275). Consent was waived by the Pathological Anatomy and Cytopathology Service Ethics Committee as this project used retrospective data from patient records, and therefore patients were not contacted. All patient data were recorded during the analysis stage and no other personally identifiable information was linked to the data.

\section{Consent for publication}

Not applicable.

\section{Competing interests}

The authors declare no potential conflicts of interest with respect to the research, authorship, and/or publication of this article.

\section{Author details}

${ }^{1}$ Department of Microbiology, Institute of Biomedical Sciences, ICB/USP, University of São Paulo, São Paulo, Brazil. ${ }^{2}$ Department of Animal Health, Faculty of Veterinary Medicine, José Eduardo dos Santos University, Huambo, Angola. ${ }^{3}$ Multidisciplinary Health Institute /Campus Anísio Teixeira, IMS/CAT - UFBA, Federal University of Bahia, Vitória da Conquista, Brazil. ${ }^{4}$ Micro - Pathological Anatomy and Cytopathology Service, Vitória da Conquista, Brazil.

Received: 15 July 2021 Accepted: 13 December 2021

Published online: 23 December 2021

\section{References}

1. Bray F, Ferlay J, Soerjomataram I, Siegel RL, Torre LA, Jemal A. Global cancer statistics 2018: GLOBOCAN estimates of incidence and mortality worldwide for 36 cancers in 185 countries. CA Cancer J Clin. 2018;68(6):394-424.

2. INCA (Instituto de Câncer José Alencar Gomes da SIlva). Estimativa 2020. Incidência do câncer no Brasil. 2019.

3. Lauren P. the Two histological main types of gastric carcinoma: diffuse and so-called intestinal-type carcinoma. An attempt at a histo-clinical classification. Acta Pathol Microbiol Scand. 1965;64:31-49.

4. Eyvazi S, Vostakolaei MA, Dilmaghani A, Borumandi O, Hejazi MS, Kahroba $\mathrm{H}$, et al. The oncogenic roles of bacterial infections in development of cancer. Microb Pathog. 2020;141(January):104019.

5. Brenna CA, Garrett WS. Fusobacterium nucleatum—symbiont, opportunist and oncobacterium. Nat Rev Microbiol. 2019;17(3):156-66.

6. Tjalsma H, Boleij A, Marchesi JR, Dutilh BE. A bacterial driver-passenger model for colorectal cancer: beyond the usual suspects. Nat Rev Microbiol. 2012;10(8):575-82.

7. Yu T, Guo F, Yu Y, Sun T, Han J, Kryczek I, et al. Fusobacterium nucleatum promotes chemoresistance to colorectal cancer by modulating autophagy. Cell. 2017;170(3):548-63.

8. Ito M, Kanno S, Nosho K, Sukawa Y, Mitsuhashi K, Kurihara H, et al. Association of Fusobacterium nucleatum with clinical and molecular features in colorectal serrated pathway. Int J Cancer. 2015;137(6):1258-68.

9. Gur C, Ibrahim Y, Isaacson B, Yamin R, Abed J, Gamliel M, et al. Binding of the Fap2 protein of fusobacterium nucleatum to human inhibitory receptor TIGIT protects tumours from immune cell attack. Immunity. 2015:42(2):344-55.

10. Baseman JB, Tully JG. Mycoplasmas: sophisticated, reemerging, and burdened by their notoriety. Emerg Infect Dis. 1997;3(1):21-32.
11. Kwon HJ, Kang JO, Cho SH, Kang HB, Kang KA, Kim JK, et al. Presence of human mycoplasma DNA in gastric tissue samples from Korean chronic gastritis patients. Cancer Sci. 2004;95(4):311-5.

12. Brown DR, May M, Bradbury JM, Johansson K-E, Neimark H. Mycoplasmatales. Bergey's Man Syst Archaea Bact. 2015;1-2.

13. Yang H, Qu L, Ma H, Chen L, Liu W, Liu C, et al. Mycoplasma hyorhinis infection in gastric carcinoma and its effects on the malignant phenotypes of gastric cancer cells. BMC Gastroenterol. 2010;10(1):132.

14. Kornspan JD, Tsur M, Tarshis M, Rottem S, Brenner T. Mycoplasma hyorhinis induces proinflammatory responses in mice lymphocytes. J Basic Microbiol. 2015;55(5):679-84.

15. Tocqueville V, Ferré S, Nguyen NHP, Kempf I, Marois-Créhana C. Multilocus sequence typing of Mycoplasma hyorhinis strains identified by a realtime TaqMan PCR assay. J Clin Microbiol. 2014;52(5):1664-71.

16. Huang S, Li JY, Wu J, Meng L, Shou CC. Mycoplasma infections and different human carcinomas. World J Gastroenterol. 2001;7(2):266-9.

17. Zhang J, Wang Y, Shou C, Xu G, Xin C, Wu J, et al. Detection of Mycoplasma hyorhinis in gastric cancer. Zhonghua Yi Xue Za Zhi. 2002;82(14):961-5.

18. Gomersall AC, Phan HA, lacuone S, Li SF, Parish RW. The mycoplasma hyorhinis p37 protein rapidly induces genes in fibroblasts associated with inflammation and cancer. PLoS ONE. 2015;10(10):1-24

19. Gong M, Meng L, Jiang B, Zhang J, Yang H, Wu J, et al. p37 from Mycoplasma hyorhinis promotes cancer cell invasiveness and metastasis through activation of MMP-2 and followed by phosphorylation of EGFR. Mol Cancer Ther. 2008;7(3):530-7.

20. Fu L, Xie C. A lucid review of Helicobacter pylori-induced DNA damage in gastric cancer. Helicobacter. 2019;24(5):1-9.

21. Duan H, Qu L, Shou C. Activation of EGFR-PI3K-AKT signaling is required for Mycoplasma hyorhinis-promoted gastric cancer cell migration. Cancer Cell Int. 2014;14(1):1-9.

22. Greer CE, Wheeler CM, Manos MM. Sample preparation and PCR amplification from Paraffin-embedded tissues. Cold Spring Harb Protoc 1994;3(6):113-22.

23. Cao W, Hashibe M, Rao JY, Morgenstern H, Zhang ZF. Comparison of methods for DNA extraction from paraffin-embedded tissues and buccal cells. Cancer Detect Prev. 2003;27(5):397-404.

24. Rabelo-Gonçalves E, Roesler B, Guardia AC, Milan A, Hara N, Escanhoela C, et al. Evaluation of five DNA extraction methods for detection of H. Pylori in formalin-fixed paraffin-embedded (FFPE) liver tissue from patients with hepatocellular carcinoma. Pathol Res Pract. 2014;210(3):142-6.

25. Lin J, Kennedy SH, Svarovsky T, Rogers J, Kemnitz JW, Xu A, et al. Highquality genomic DNA extraction from formalin-fixed and paraffinembedded samples deparaffinized using mineral oil. Anal Biochem. 2009;395(2):265-7.

26. Mesquita RA, Anzai EK, Oliveira RN, Nunes FD. Evaluation of 3 methods of DNA extraction from paraffin-embedded material for the amplification of genomic DNA using PCR. Pesqui Odontol Bras. 2001;15(4):314-9.

27. Alvarez-Aldana A, Martínez JW, Sepúlveda-Arias JC. Comparison of five protocols to extract DNA from paraffin-embedded tissues for the detection of human papillomavirus. Pathol Res Pract. 2015:211(2):150-5.

28. Green MR, Sambrook J. Isolation of high-molecular-weight DNA from mammalian tissues using proteinase K and phenol. Cold Spring Harb Protoc. 2017;2017(3):260-4.

29. Saiki RK, Scharf S, Faloona F, Mullis KB, Horn GT, Erlich HA, et al. Enzymatic amplification of,-globin genomic sequences and restriction site analysis for diagnosis of sickle cell anemia. Science (80- ). 1985;230:1350-4.

30. Friis NF. Mycoplasmas cultivated from the respiratory tract of Danish pigs. Acta Vet Scand. 1971;12(1):69-79.

31. Tully JG. Culture medium formulation for primary isolation and maintenance of mollicutes. In: Razin S, Tully JG, editors. Molecular and diagnostic procedures in mycoplasmology. San Diego: Academic Press; 1995. p. 33-9.

32. Van Kuppeveld FJM, Van der Logt JTM, Angulo AF, Van Zoest MJ, Quint WGV, Niesters HGM, et al. Genus- and species-specific identification of mycoplasmas by 165 rRNA amplification. Appl Environ Microbiol. 1992;58(8):2606-15.

33. Pirouz T, Zounubi L, Keivani H, Rakhshani N, Hormazdi M. Detection of helicobacter pylori in paraffin-embedded specimens from patients with chronic liver diseases, using the amplification method. Dig Dis Sci. 2009:54(7):1456-9. 
34. Timenetsky J, Santos LM, Buzinhani M, Mettifogo E. Detection of multiple mycoplasma infection in cell cultures by PCR. Braz J Med Biol Res. 2006;39(7):907-14.

35. Coffey J, Choudhry M, Shlossman M, Makin IRS, Singh VK. Multiplex realtime PCR detection and relative quantification of periodontal pathogens. Clin Exp Dent Res. 2016;2(3):185-92.

36. Kornspan JD, Tarshis M, Rottem S. Invasion of melanoma cells by Mycoplasma hyorhinis: enhancement by protease treatment. Infect Immun. 2010;78(2):611-7.

37. Duan H, Chen L, Qu L, Yang H, Song SW, Han Y, et al. Mycoplasma Hyorhinis infection promotes NF-kB-dependent migration of gastric cancer cells. Cancer Res. 2014;74(20):5782-94.

38. Brierley JD, Gospodarowicz MK, Wittekind C. TNM Classification of malignant tumours. In: Brierley JD, Gospodarowicz MK, Wittekind C, editors. Union for international cancer control, 8th ed (2017).

39. Urbanek C, Goodison S, Chang M, Porvasnik S, Sakamoto N, Li CZ, et al. Detection of antibodies directed at M. hyorhinis p37 in the serum of men with newly diagnosed prostate cancer. BMC Cancer. 2011;11.

40. Zella D, Curreli S, Benedetti F, Krishnan S, Cocchi F, Latinovic OS, et al. Mycoplasma promotes malignant transformation in vivo, and its DnaK, a bacterial chaperon protein, has broad oncogenic properties. Proc Natl Acad Sci USA. 2018;115(51):E12005-14.

41. Bullman S, Pedamallu CS, Sicinska E, Clancy TE, Cai D, Neuberg D, et al. Analysis of Fusobacterium persistence and antibiotic response in colorectal cancer. Science (80- ). 2017;358(6369):1443-8.

42. Gilbert MTP, Haselkorn T, Bunce M, Sanchez JJ, Lucas SB, Jewell LD, et al. The isolation of nucleic acids from fixed, paraffin-embedded tissueswhich methods are useful when? PLOS ONE. 2007;2(6).

43. Okello JBA, Zurek J, Devault AM, Kuch M, Okwi AL, Sewankambo NK, et al. Comparison of methods in the recovery of nucleic acids from archival formalin-fixed paraffin-embedded autopsy tissues. Anal Biochem. 2010;400(1):110-7.

44. Yow MA, Tabrizi SN, Severi G, Bolton DM, Pedersen J, Longano A, et al. Detection of infectious organisms in archival prostate cancer tissues. BMC Cancer. 2014;14:579.

45. Wroblewski LE, Peek RM, Coburn LA. The role of the microbiome in gastrointestinal cancer. Gastroenterol Clin North Am. 2016;45(3):543-56.

46. Benedetti F, Curreli S, Zella D. Mycoplasmas-host interaction: mechanisms of inflammation and association with cellular transformation. Microorganisms. 2020;8(9):1-21.

47. Wang Y, Wang Q, Li Y, Chen Y, Shao J, Nick N, et al. Mmm-derived lipidassociated membrane proteins activate IL-1 $\beta$ production through the NF-KB pathway via TLR2, MyD88, and IRAK4. Sci Rep. 2017;7(1):1-9.

48. Yu QW, Wang H, Huo JT, An XF, Gao P, Jiang ZZ, et al. Suppression of Baeckea frutescens $L$. and its components on MyD88-dependent NF-KB pathway in MALP-2-stimulated RAW264.7 cells. J Ethnopharmacol. 2017;207(May):92-9.

49. Galanos C, Gumenscheimer M, Mühlradt PF, Jirillo E, Freudenberg MA. MALP-2, a Mycoplasma lipopeptide with classical endotoxic properties: end of an era of LPS monopoly? J Endotoxin Res. 2000;6(6):471-6.

50. Benedetti F, Cocchi F, Latinovic OS, Curreli S, Krishnan S, Munawwar A et al. Role of mycoplasma chaperone dnak in cellular transformation. Int J Mol Sci. 2020;21(4).

51. Zhang S, Tsai S, Lo SC. Alteration of gene expression profiles during mycoplasma-induced malignant cell transformation. BMC Cancer. 2006;6:1-11.

52. Okumura T, Ericksen RE, Takaishi S, Wang SSW, Dubeykovskiy Z, Shibata W, et al. K-ras mutation targeted to gastric tissue progenitor cells results in chronic inflammation, an altered microenvironment, and progression to intraepithelial neoplasia. Cancer Res. 2010;70(21):8435-45.

53. IARC Working Group on the Evaluation of Carcinogenic Risks to Humans. Part B: Biological agents. In: A review of human carcinogens [Internet]. 2009. p. 1-499. https://monographs.iarc.fr/agents-classified-by-the-iarc/

54. Lin YS, Chen MJ, Shih SC, Bair MJ, Fang CJ, Wang HY. Management of Helicobacter pylori infection after gastric surgery. World J Gastroenterol. 2014;20(18):5274-82

55. Ramaswamy A, Lin E, Ramshaw BJ, Smith D. Early effects of helicobacter pylori infection in patients undergoing bariatric surgery. Arch Surg. 2004;139(10):1094-6.
56. Chmiela M, Karwowska Z, Gonciarz W, Allushi B, Staczek P. Host pathogen interactions in Helicobacter pylori related gastric cancer. World J Gastroenterol. 2017;23(9):1521-40.

57. Kusters JG, Van Vliet AHM, Kuipers EJ. Pathogenesis of Helicobacter pylori infection. Clin Microbiol Rev. 2006;19(3):449-90.

58. Mnich E, Kowalewicz-Kulbat M, Sicinska P, Hinc K, Obuchowski M, Gajewski A, et al. Impact of helicobacter pylori on the healing process of the gastric barrier. World J Gastroenterol. 2016;22(33):7536-58.

59. Kuo SH, Chen LT, Lin CW, Yeh KH, Shun CT, Tzeng YS, et al. Expressions of the CagA protein and CagA-signaling molecules predict Helicobacter pylori dependence of early-stage gastric DLBCL. Blood. 2017;129(2):188-98.

60. Tatemichi M, Sasazuki S, Inoue M, Tsugane S. Different etiological role of Helicobacter pylori $(\mathrm{Hp})$ infection in carcinogenesis between differentiated and undifferentiated gastric cancers: a nested case-control study using lgG titer against Hp surface antigen. Acta Oncol (Madr). 2008;47(3):360-5.

61. Kakinoki R, Kushima R, Matsubara A, Saito Y, Okabe H, Fujiyama Y, et al. Re-evaluation of histogenesis of gastric carcinomas: a comparative histopathological study between helicobacter pylori-negative and $\mathrm{H}$. pylori-positive cases. Dig Dis Sci. 2009;54(3):614-20.

62. Kim N, Jung HC. The role of serum pepsinogen in the detection of gastric cancer. Gut Liver. 2010;4(3):307-19.

63. Kudo Y, Morohashi S, Takasugi K, Tsutsumi S, Ogasawara H, Hanabata N, et al. Histopathological phenotypes of early gastric cancer and its background mucosa. Biomed Res. 2011;32(2):127-34.

64. Kim J, Cho YA, Choi IJ, Lee YS, Kim SY, Shin A, et al. Effects of interleukin-10 polymorphisms, helicobacter pylori infection, and smoking on the risk of noncardia gastric cancer. PLoS ONE. 2012;7(1).

65. Boehm ET, Thon C, Kupcinskas J, Steponaitiene R, Skieceviciene J, Canbay A, et al. Fusobacterium nucleatum is associated with worse prognosis in Lauren's diffuse type gastric cancer patients. Sci Rep. 2020;10(1):1-12.

66. Guo P, Tian Z, Kong X, Yang L, Shan X, Dong B, et al. FadA promotes DNA damage and progression of Fusobacterium nucleatum-induced colorectal cancer through up-regulation of chk2. J Exp Clin Cancer Res. 2020;39(1):1-13.

67. Yamamoto S, Kinugasa H, Hirai M, Terasawa H, Yasutomi E, Oka S, et al. Heterogeneous distribution of Fusobacterium nucleatum in the progression of colorectal cancer. J Gastroenterol Hepatol. 2021;36(7):1869-76.

68. Mitsuhashi K, Nosho K, Sukawa Y, Matsunaga Y, Ito M, Kurihara H, et al. Association of Fusobacterium species in pancreatic cancer tissues with molecular features and prognosis. Oncotarget. 2015:6(9):7209-20.

69. Chernov AV, Reyes L, Xu Z, Gonzalez B, Golovko G, Peterson S, et al. Mycoplasma CG- and GATC-speci fi c DNA methyltransferases selectively and ef fi ciently methylate the host genome and alter the epigenetic landscape in human cells. Epigenetics. 2015;10(April):303-18.

70. Wojciechowski M, Czapinska H, Bochtler M. CpG underrepresentation and the bacterial. Proc Natl Acad Sci. 2013;110(1):105-10.

71. Maeda M, Moro H, Ushijima T. Mechanisms for the induction of gastric cancer by Helicobacter pylori infection: aberrant DNA methylation pathway. Gastric Cancer. 2017;20(s1):8-15.

72. Zinatizadeh MR, Masoumalinejad Z, Parnak F. The prevalence of Mycoplasma hyorhinis contamination in tissues samples from cancer patients: a brief report. Mod Med Lab J. 2018;1(3):91-5.

73. Kannangara DKS, Lokuhetty MDS, Subasinghe D, Gunawardene YINS, Dassanayake RS. Could quantitative real-time polymerase chain reaction assay serve as an alternative test method to evaluate human epidermal growth factor receptor 2 status of gastric carcinoma in the South Asian setting? Indian J Gastroenterol. 2019;38(4):317-24.

74. Rajalingam K, Schreck R, Rapp UR, Albert Š. Ras oncogenes and their downstream targets. Biochim Biophys Acta. 2007;1773:1177-95.

\section{Publisher's Note}

Springer Nature remains neutral with regard to jurisdictional claims in published maps and institutional affiliations. 